\title{
Adolescent Girls Initiative-Kenya: Program overview
}

Population Council

Follow this and additional works at: https://knowledgecommons.popcouncil.org/departments_sbsr-pgy

Part of the Demography, Population, and Ecology Commons, Family, Life Course, and Society Commons, Gender and Sexuality Commons, and the International Public Health Commons How does access to this work benefit you? Let us know!

\section{Recommended Citation}

"Adolescent Girls Initiative-Kenya: Program overview," fact sheet. Nairobi: Population Council, 2015. 

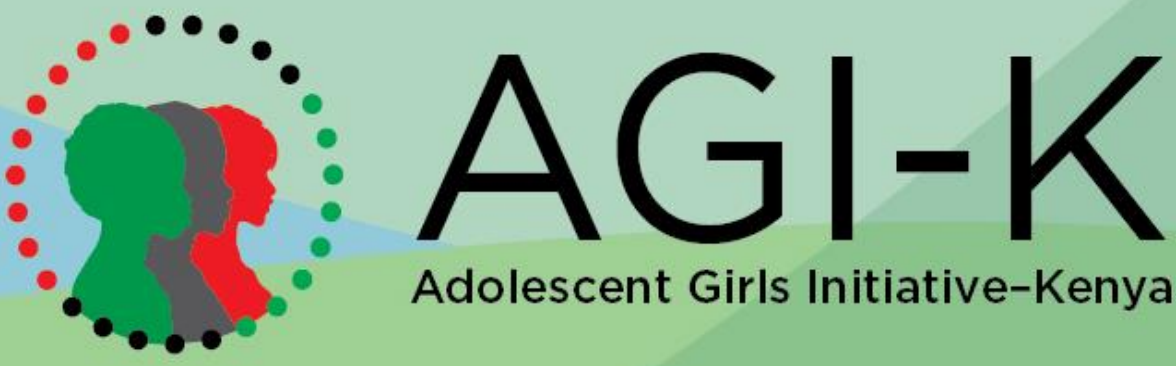

Adolescent Girls Initiative-Kenya

\section{INTRODUCTION}

Many adolescent girls in Kenya face considerable risks and vulnerabilities that affect their education, health, and general well-beingincluding early marriage; teenage pregnancy; early, unprotected, and/or unwanted sexual activity; violence; social isolation; and HIV/STIs.

For the most part, very young adolescent girls (younger than age 15) who live in risk-prone environments have not yet experienced these negative outcomes. It is critical, therefore, to intervene early and increase girls' capacity to overcome these risks before the challenges result in outcomes that may be irreversible.

Research has shown that single-sector interventions are not adequate to obtain the range of outcomes needed to help girls enter into adulthood in a healthy, safe and productive manner. However, there is insufficient evidence regarding the most cost-effective combination of multi-sectoral interventions to achieve the greatest positive impact on girls' well-being.

The Adolescent Girls Initiative-Kenya (AGI-K) will deliver multi-sectoral interventions for 6,000 girls ages 11-14 in two marginalized areas of Kenya: the Kibera slums in Nairobi and Wajir County in Northeastern Kenya.

Interventions will run for two years and include a combination of girl-, household- and community-level interventions. The longitudinal research study will compare the impact of four different packages of interventions:

1) violence prevention only

2) violence prevention + education

3) violence prevention + education + health

4) violence prevention + education + health + wealth creation

In addition, careful costing data will be collected in order to understand the cost-effectiveness of the impact achieved in each package. Recommendations for scale up can then be made to policymakers and other key stakeholders.

\section{PROGRAM COMPONENTS}

\section{Violence Prevention}

The violence prevention intervention will employ community-level dialogues and contracts. A committee will be established in each community and will include religious and community leaders, parents, teachers, and young men and women. The group will be led through a facilitated process to identify key issues in the community that lead to the under-valuing of girls and the perpetuating of violence against girls and women. The committee will develop a "contract" including specific steps that they will take to address those issues and an action plan for implementing the related activities.

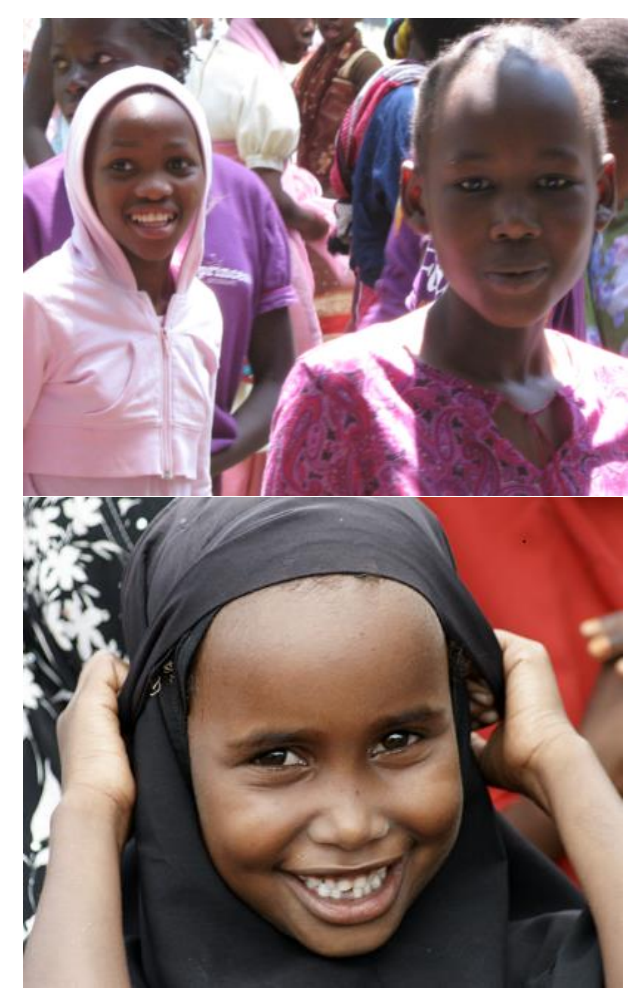

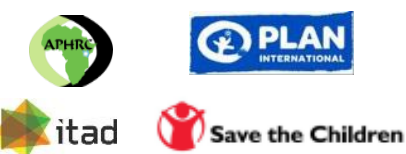




\section{Education}

The education intervention will involve a cash transfer conditional on $80 \%$ attendance during each school term. At the start of the intervention, all girls-whether in school or out of school-will be eligible for the transfer upon enrollment. The four components of the conditional transfer include:

1) fees, if applicable, to be paid directly to the school at the start of each term,

2) a cash transfer made to the head of household, to be paid twice per term. The payment amount in Kibera is 1,125 Kenyan Shillings (approx. US\$11) and in Wajir the amount is 1,500 Kenyan Shillings (approx. US\$15.50).

3) schooling kits given directly to girls at the start of each term containing sanitary towels, panties, and basic school supplies; and

4) an incentive paid directly to the school of 500 Kenyan Shillings (approx. US\$5.25) per girl enrolled in the cash transfer program.

\section{Health}

The health intervention is based on the Population Council's safe spaces model in which girls meet in groups once a week under the guidance of a female mentor from the community. Groups will be segmented by age (1112-year-olds in one group and 13-14-year-olds in the other) in Nairobi, and by schooling status in Wajir. Group meetings will include facilitated discussions using a health, life skills, and nutrition curriculum, as well as time for open discussion.

\section{Wealth Creation}

The wealth creation intervention will include a financial education (FE) curriculum integrated into the safe spaces group meetings. In Wajir girls will receive a home bank (piggybank), and in Kibera girls will open a girl-friendly savings account with the Kenya Post Office Savings Bank (Postbank). They will also receive a small annual incentive (\$3.20) to allow them to put into practice the skills learned in the FE sessions.

\section{RESEARCH OVERVIEW}

Using a randomized controlled trial design, researchers will conduct a rigorous impact evaluation of the program. Randomization to intervention packages is at the individual level in Kibera and at the village level in Wajir. The study will follow girls for the two-year intervention period and for two years after completion of the intervention. Using both quantitative and qualitative methods, the program evaluation will examine the impact of the intervention packages while identifying the causal mechanisms driving that impact. Surveys will cover a wide range of topics, including education history, self-esteem, social networks, attitudes and behaviors related to gender, work and savings activity, nutrition status, literacy and numeracy skills, cognitive function, sexual and reproductive health knowledge, marriage history, and sexual behavior.

\section{TIMELINE}

Baseline data was collected between February and May 2015. Interventions in both locations will begin in June 2015 , and all program activities will begin by September 2015. The interventions will be completed by May 2017 , and endline data will be collected between June and August 2017. A follow-up round of data to assess the sustained impact of the interventions will be collected between June and August 2019.

This program is funded by the UK Department for International Development (DFID). The project will be implemented by a highly qualified consortium, led by the Population Council in partnership with the African Population and Health Research Center (APHRC) and Itad as research partners, Save the Children in Kenya as the implementing partner in Wajir County, and Plan International-Kenya as the implementing partner in Kibera.

\section{CONTACT INFORMATION}

For more information about AGI-K, call +254-20-2713480

or email agi@popcouncil.org or visit: www.popcouncil.org/research/adolescent-girlsinitiative-action-research-program
Population Council General Accident House, 2nd Floor

Ralph Bunche Road

PO Box 17643-00500

Nairobi, Kenya

Photo credits: Top-Karen Austrian; Bottom-Jerome Taylor/Save the Children 